Proc. Indian Acad. Sci. (Earth Planet. Sci.), Vol. 103, No. 1, March 1994, pp. 83-97.

(C) Printed in India.

\title{
New age constraints on the cooling and unroofing history of the Trans-Himalayan Ladakh Batholith (Kargil area), N. W. India
}

\author{
RASOUL B SORKHABI ${ }^{1 *}$, ARVIND K JAIN ${ }^{2}$, \\ SUSUMU NISHIMURA ${ }^{1}$, TETSUMARU ITAYA ${ }^{3}$, NAND LAL ${ }^{4}$, \\ R M MANICKAVASAGAM ${ }^{2}$, TAKAHIRO TAGAMI ${ }^{1}$ \\ ${ }^{1}$ Department of Gcology and Mineralogy, Faculty of Science, Kyoto University, Kyoto 606, \\ Japan \\ ${ }^{2}$ Department of Earth Sciences, University of Roorkee, Roorkee 247667 , India \\ ${ }^{3}$ Hiruzen Research Institute, Okayama University of Science, 1-1 Ridaicho, Okayama 700, \\ Japan \\ -Department of Physics, Kurukshetra University, Kurukshetra 132119 , India \\ *Also Department of Geology, Arizona State University, Tempe, AZ 85287-1404, USA
}

MS received 3 July 1993; revised 22 April 1994

\begin{abstract}
Thermotectonic history of the Trans-Himalayan Ladakh Batholith in the Kargil area, $N$. W. India, is inferred from new age data obtained here in conjunction with previously published ages. Fission-track (FT) ages on apatite fall around $20 \pm 2 \mathrm{Ma}$ recording cooling through temperatures of $\sim 100^{\circ} \mathrm{C}$ and indicating an unroofing of $4 \mathrm{~km}$ of the Ladakh Range since the Early Miocene. Coexisting apatite and zircon FT ages from two samples in Kargil show the rocks to have cooled at an average rate of $5-6^{\circ} \mathrm{C} / \mathrm{Ma}$ in the past $40 \mathrm{Ma}$. Zircon FT ages together with mica $\mathrm{K}$-Ar cooling ages from the Ladakh Batholith cluster around 40-50 Ma, probably indicating an Eocene phase of uplift and erosion that affected the bulk of the batholith after the continental collision of India with the Ladakb arc at $55 \mathrm{Ma}$. Components of the granitoids in Upper Eocene-Lower Oligocene sediments of the Indus Molasse in Ladakh supports this idea. Three hornblende $\mathrm{K}-\mathrm{Ar}$ ages of $90 \mathrm{Ma}, 55 \mathrm{Ma}$, and $35 \mathrm{Ma}$ are also reported; these distinctly different ages probably reflect cooling through $500-550^{\circ} \mathrm{C}$ of three phases of I-type plutonism in Ladakh also evidenced by other available radiometric data: $102 \mathrm{Ma}$ (mid-Cretaceous), $60 \mathrm{Ma}$ (Palaeocene), and $40 \mathrm{Ma}$ (Late Eocene); the last phase being localised sheet injections. The geodynamic implications of the age data for the India-Asia collision are discussed.
\end{abstract}

Keywords. The Himalayas; Ladakh Batholith; collision tectonics; geochronology; fissiontrack dating.

\section{Introduction}

The palaeo-subduction zone between the Indian and Asian plates, where consumption of the Neo-Tethyan ocean and subsequent continental collision took place, is represented by the Indus-Tsangpo Suture Zone (ITSZ), consisting of ophiolitic melange belts, high-pressure blueschist metamorphics, tholeiitic volcanics, deep-sea sediments and flysch deposits (e.g. Gansser 1980). A remarkable feature to the north of the ITSZ is the Trans-Himalayan Batholith, a linear plutonic complex extending for nearly $2500 \mathrm{~km}$ along the Himalayan orogenic belt, believed to be due to the subduction of the Neo-Tethyan ocean crust. Radiometric ages from these magmatic rocks not only place time constraints on the closure of the Neo-Tethys but also reveal the thermal and unroofing history of the Ladakh Range and its tectonic relations to the India-Asia continental collision. 
The ITSZ and the Trans-Himalayan Batholith can be divided into three sectors from west to east - Kohistan, Ladakh, and South Tibet (comprising the Kailash and Gandese plutonic complexes) - separated from each other by the Nanga Parbat promontory of the Indian plate and the Karakorum strike-slip fault, respectively (figure 1a). Zeitler (1985a) and Treloar et al (1989) determined the cooling and denudation history of the Kohistan Batholith. Ladakh holds a key position between Kohistan and South Tibet. Age data from this region are, however, both scarce and scattered. The purposes of this paper are: (i) to report new fission-track (FT) and potassium-argon (K-Ar) mineral ages from the Kargil intrusives in SW Ladakh, and (ii) to infer the thermotectonic timing of the Ladakh Batholith based on our results and other available geochronologic data.

In view of the complex nature of processes and events that have led to Himalayan orogency, radiometric data are significant because they constrain the temporal evolution of the India-Asia collisional tectonics and help us test various tectonic models for the Himalaya. It should be noted that the FT ages in the present study, unlike previous reports (Lal and Nagpaul 1975; Sharma 1980; Agarwal and Sharma 1986), have been determined by internationally-established procedures (Naeser 1976; Tagami et al 1988) constrained by age standards (Hurford 1990) and some fissiontrack length measurements (Gleadow et al 1986).

The basis of geothermochronology is the difference in closure temperatures of parent-daughter radioactive systems in different minerals; the closure (or blocking) temperature being a certain temperature range below which a mineral becomes closed to parent-daughter migration, and the radiometric clock is set. In FT dating, fission tracks in uranium-bearing minerals of apatite and zircon are annealed above a certain temperature range for each of these minerals but start to accumulate below those temperature ranges. Therefore, differences in the radiometric ages of different minerals reflect cooling histories of rocks (e.g. Wagner et al 1977; Harrison and McDougall 1980).

\section{Tectonic setting}

The Ladakh Batholith (figure 1b) occurs in an elongated arc, convex northward, measuring about $600 \mathrm{~km}$ in length, $20-80 \mathrm{~km}$ in width, with $2.5-3.2 \mathrm{~km}$ of vertical exposure (Sharma and Choubey 1983). It contains multiple intrusions which vary in composition from norite and gabbro, through diorite and tonalite, to granodiorite and granite; many dykes also cut across these rocks (Rai and Pande 1978; Honegger et al 1982; Rai 1983). From aerial photographs and geological mapping, their relative distribution has been estimated by Honegger et al (1982) to be about $50 \%$ granodiorite, $20-30 \%$ intermediate granitoids, $10-20 \%$ mafic intrusives, and about $10 \%$. biotite granite. Sharma and Choubey (1983) have classified the southern margin of the Ladakh granitoids into four types: Type I (quartz monzodiorite and granodiorite) constituting the bulk of the batholith; Type II (hornblende-bearing porphyritic granite) best exposed in central Ladakh (between Hanuthang and Achinithang); Type III (biotite-bearing leucogranite); and Type IV (biotite-bearing porphyritic granite) outcropping between Upshi-Giak-Chumathang in eastern Ladakh.

In Ladakh (as in Kohistan), the batholith is situated between the Indus(-Tsangpo) Suture to the south and the Northern (Shyok) Suture (Gansser 1980). The latter seems 


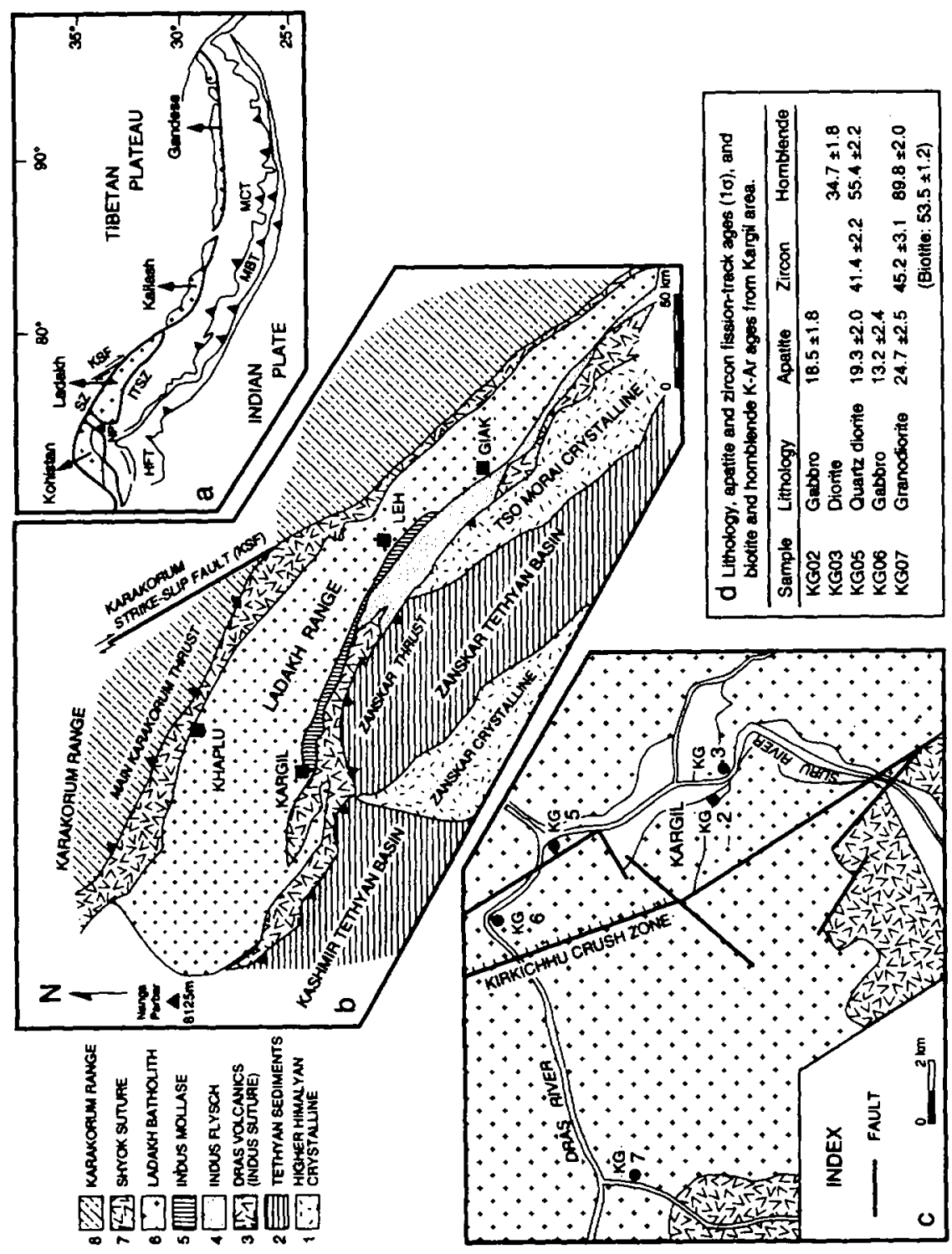

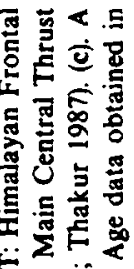
志客完

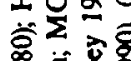
焉 密究它 营范

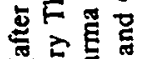
焉密密 言点密

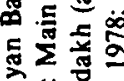
焉泀范

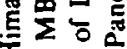

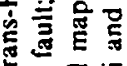

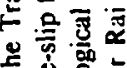

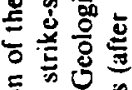

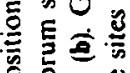

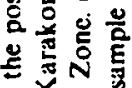

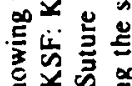
递密 氖芒总 出并

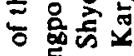
总芯导

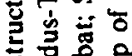

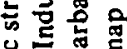
象定 造皆 递要品

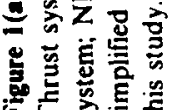


to have formed due to the closure of a back-arc basin probably earlier than the Indus Suture during Late Cretaceous. The time of India-Asia continental collision in the Ladakh region has been estimated to be $55 \mathrm{Ma}$ (Klootwijik 1984; Searle et al 1987) based on palaeomagnetic and stratigraphic evidence. In the Kargil area, plutonic rocks intrude the Cretaceous Dras Volcanics and are overlain by the Tertiary Indus Molasse sediments (Frank et al 1977; Honegger et al 1982).

\section{Experimental procedure}

Several granitoid samples were collected around Kargil at altitudes of $2700 \pm 80 \mathrm{~m}$ (figure 1c). Minerals separation from crushed rock samples was made using a Frantz magnetic separator and organic heavy liquids. FT dating was carried out by the external detector method (Naeser 1976; Tagami et al 1988). Apatites mounted in epoxy resin were etched in $0.6 \% \mathrm{HNO}_{3}$ at $32^{\circ} \mathrm{C}$ for 90 seconds; zircons mounted in PFA Teflon were etched in $\mathrm{KOH}-\mathrm{NaOH}$ melt at $225^{\circ} \mathrm{C}$ for 45 hours to reveal spontaneous fission tracks. Muscovite detectors were etched in $48 \% \mathrm{HF}$ at $32^{\circ} \mathrm{C}$ for four minutes to reveal induced tracks. The mineral mounts and the dosimeter glass NBS-SRM612 were irradiated in the TRIGA II reactor of the Musashi Institute of Technology (Japan). FT ages were calculated using the zeta calibration approach (Hurford 1990).

For $\mathrm{K}$-Ar dating, potassium content was measured by flame photometry using a $2000 \mathrm{ppm} \mathrm{Cs}$ buffer, argon was extracted in $\mathrm{Mb}$ crucible at $1500-1600^{\circ} \mathrm{C}$, purified by a $\mathrm{Ti}-\mathrm{Zr}$ scrubber, and analyzed on a $15 \mathrm{~cm}$ radius sector-type mass spectrometer, using the ${ }^{38} \mathrm{Ar}$ as spike for isotopic dilution. The constants used follow Steiger and Jager (1977).

Some age standard samples were also dated along with unknown samples, and several of the unknown samples were analyzed more than once; yielding reproducible results.

Measurements of confined fission tracks (i.e. horizontal to polished surface) in apatite has proved to be a diagnostic tool for thermal history analysis of rocks (Gleadow et al 1986). Fission tracks subjected to varying temperatures-time pathways will experience varying degrees of annealing, and this thermal history will be documented in the fission-track lengths because annealing occurs with shrinking of the track length (Naeser 1976). Therefore, track-length measurements reveal whether the minerals containing fission tracks have or have not resided in the partial annealing zones of fission tracks during their uplift from depths to the surface. In this way, precise implications of obtained FT ages are understood. One significant problem in applying the track-length studies to Himalayan rock samples is that most of these samples are geologically young and/or poor in uranium content so that they do not yield sufficient number of confined tracks for a statistically meaningful measurement. In the case of active orogenic belts such as the Himalaya which have undergone enormous amount of uplift/denudation during a geologically short span of time, it is possibly safe to assume that FT ages generally (but not always) record their effective closure temperatures. In this study we have been able to carry out track-length measurements on apatite and zircon for one sample, which supports such an assumption. 


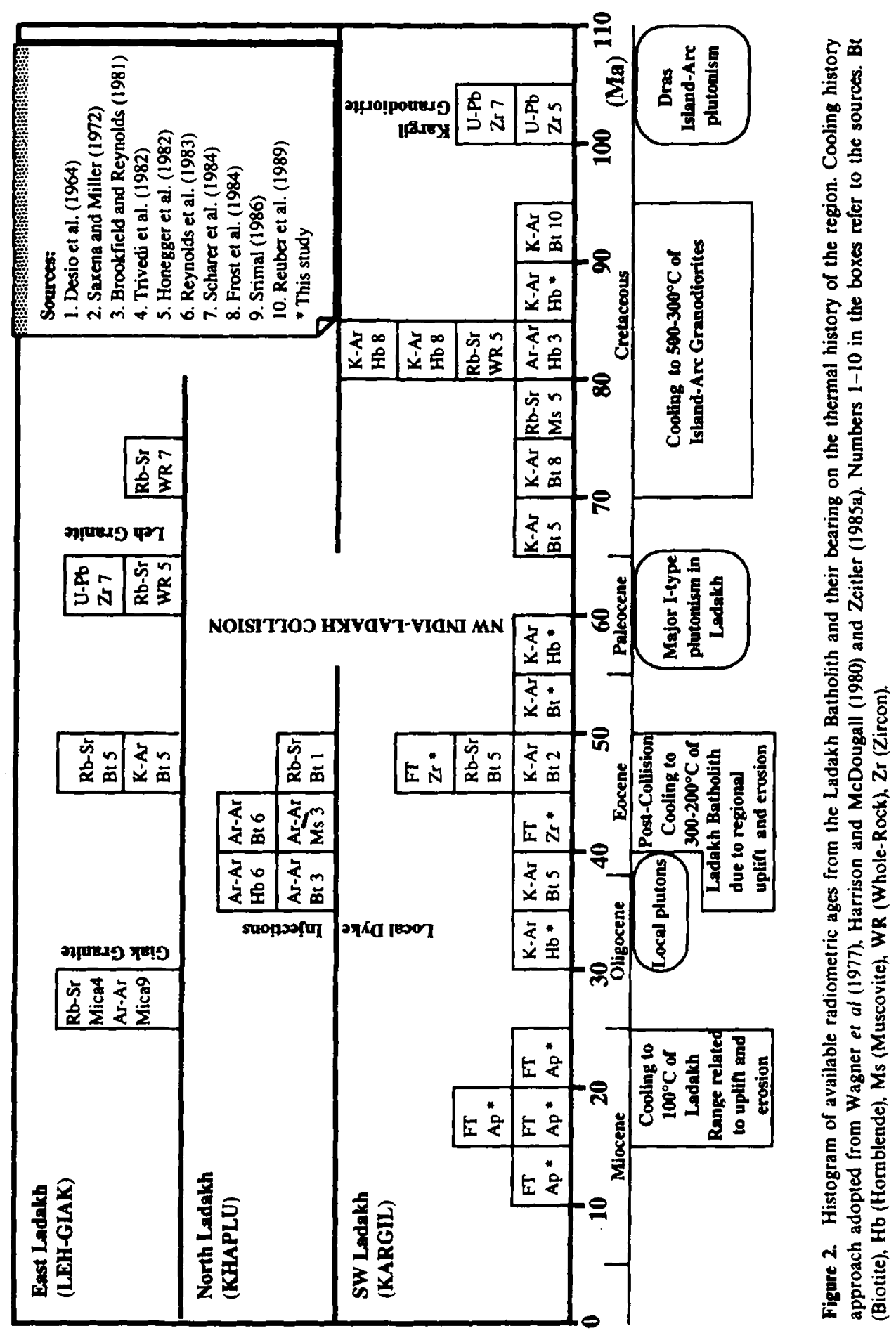




\section{Results and discussion}

The FT and $\mathrm{K}$-Ar ages are given in figure 1d. Tables 1 and 2 present the analytical data, respectively. Figure 2 shows the distribution of age data on the Ladakh Batholith from this study and earlier reports. Figure 3 shows the fission-track length distributions in apatite and zircon for sample KG05.

\subsection{Apatite fission-track ages}

Apatite FT ages from four granitoids in Kargil range from 13.2 $\pm 2.4(1 \sigma)$ through $19 \mathrm{Ma}$ to $24.7 \pm 2.5 \mathrm{Ma}(1 \sigma)$. Within 2 sigma uncertainty (i.e. 95 per cent confidential level), all the four ages fall around $20 \pm 2 \mathrm{Ma}$. One sample (KG06, a gabbro) yielded a relatively younger age of $13 \pm 4 \cdot 8(2 \sigma)$. Although, this age falls within the mean age of $20 \pm 2 \mathrm{Ma}$, it is to be noted that unlike the apatite ages of other samples, that of KG03 does not pass the $\chi 2$ test at 5\%, indicating non-Poisonnian scatter (Galbraith 1981). This is probably due to a younger thermal overprint related to the activity of faults bounding this rock (figure 1c). Due to low density of apatite fission tracks in KG06, track-length measurements could not be made to verify this idea. KG06 was collected from a site very close to the "Kirkichhu crush zone" mapped by Sharma

Table 1. Fission track analytical data of the Kargil plutonic rocks.

\begin{tabular}{|c|c|c|c|c|c|c|c|c|c|c|}
\hline Sample & $n$ & $\begin{array}{c}\rho_{s} \times 10^{6} \\
\left(\mathrm{~cm}^{-2}\right)\end{array}$ & $N_{s}$ & $\begin{array}{l}\rho_{1} \times 10^{6} \\
\left(\mathrm{~cm}^{-2}\right)\end{array}$ & $N_{i}$ & $\begin{array}{c}\rho_{d} \times 10^{6} \\
\left(\mathrm{~cm}^{-2}\right)\end{array}$ & $N$ & $r$ & $\begin{array}{c}P\left(\chi^{2}\right) \\
(\%)\end{array}$ & $\begin{array}{c}\text { Age } \pm 1 \sigma \\
(\mathrm{Ma})\end{array}$ \\
\hline \multicolumn{11}{|l|}{ APATITE } \\
\hline KG02 & 10 & 0.2151 & 130 & 10608 & 641 & 0.5538 & 4633 & 0.814 & 65 & $18.5 \pm 1.8$ \\
\hline KGOS & 12 & 0.3330 & 125 & $1 \cdot 5773$ & 592 & 0.5538 & 4633 & 0.793 & 95 & $19.3 \pm 2.0$ \\
\hline KG06 & 8 & 0.2930 & 112 & 2.5635 & 980 & 0.5538 & 4633 & 0.046 & $<1$ & $13.2 \pm 2.4$ \\
\hline KG07 & 32 & & & & & & & & & $24 \cdot 7 \pm 2 \cdot 5$ \\
\hline KG07A & 12 & $0-0795$ & 45 & 0.3110 & 176 & 0.5538 & 4633 & 0.711 & $>99$ & $23 \cdot 3 \pm 4 \cdot 0$ \\
\hline KG07B & 9 & 00719 & 31 & 0.2598 & 112 & 0.5538 & 4633 & $0-073$ & 90 & $25 \cdot 2 \pm 5 \cdot 1$ \\
\hline KG07C & 11 & $0-0710$ & 57 & 0.1719 & 138 & 0.3756 & 3404 & 0749 & 70 & $25 \cdot 6 \pm 4 \cdot 0$ \\
\hline \multicolumn{11}{|l|}{ ZIRCON } \\
\hline KGOS & 18 & & & & & & & & & $41 \cdot 4 \pm 2 \cdot 2$ \\
\hline KG05A & 8 & $2 \cdot 2375$ & 455 & $1 \cdot 3868$ & 282 & 0.1469 & 3192 & 0.639 & 65 & $41 \cdot 2 \pm 3 \cdot 2$ \\
\hline KG0SB & 10 & 1.8657 & 568 & $1 \cdot 1464$ & 349 & 0.1469 & 3192 & 0.679 & 10 & $41.5 \pm 2.9$ \\
\hline KG07 & 17 & & & & & & & & & $45 \cdot 2 \pm 3 \cdot 1$ \\
\hline KG07A & 9 & 2.4438 & 345 & $1 \cdot 3434$ & 192 & 0.1469 & 3192 & 0.909 & 98 & $45 \cdot 8 \pm 4 \cdot 2$ \\
\hline KG07B & 8 & 1.8726 & 272 & 1.0740 & 156 & 0.1469 & 3192 & -0.117 & 70 & $44 \cdot 5 \pm 4 \cdot 5$ \\
\hline \multicolumn{11}{|c|}{ FISH CANYON TUFF (Age standard; $27.4 \pm 0.4 \mathrm{Ma}$; Hurford and Hammerschmidt 1985) } \\
\hline APATITE & 15 & 0.2005 & 140 & 0.7432 & 519 & 0.6169 & 4301 & 0799 & 99 & $27 \cdot 4 \pm 2 \cdot 6$ \\
\hline ZIRCON & 11 & $5 \cdot 5437$ & 1881 & 4.9955 & 1695 & 0.1406 & 2059 & 0.883 & 15 & $27 \cdot 1 \pm 1 \cdot 1$ \\
\hline
\end{tabular}

$\rho_{z}=$ spontaneous fission track density; $N_{s}=$ total number of spontaneous fission tracks counted; $\rho_{i}=$ induced fission track density; $N_{i}=$ total number of induced fission tracks counted; $\rho_{d}=$ induced fission track density in the dosimeter glass NBS-SRM612; $N_{d}=$ total number of induced tracks counted to determine $\rho_{d} ; n=$ number of grains counted; $r=$ correlation coefficient between individual track counts; $P(\chi 2)=$ probability of obtaining the observed $\chi 2$ value for $n$ (number of crystals -1 ) degree of freodom (Galbraith 1981) which is quoted to nearest $5 \%$ and ages failing the $\chi 2$ test at $5 \%$ were calculated by the mean $\rho_{s} / \rho_{l}$ ratio (Green 1981). Zeta values used for calculating ages were 330 for apatite, and 348 for zircon. 
Table 2. $\mathrm{K}$-Ar analytical data of hornblende $(\mathrm{Hb})$ and biotite $(\mathrm{Bt})$ from the Kargil plutonic rocks.

\begin{tabular}{lcccc}
\hline Sample & $\begin{array}{c}\mathrm{K} \\
(\%)\end{array}$ & $\begin{array}{c}\text { Rad. Ar-40 } \\
\left(10^{-8} \text { ccSTP/gm) }\right.\end{array}$ & $\begin{array}{c}\text { Non-Rad. } \\
\text { Ar }(\%)\end{array}$ & $\begin{array}{c}\text { Age } \\
(\mathrm{Ma})\end{array}$ \\
\hline KG03(Hb) & 0.32 & $43 \cdot 6$ & $32 \cdot 5$ & $34 \cdot 7 \pm 1 \cdot 8^{*}$ \\
KG05(Hb) & & & & $55 \cdot 4 \pm 2 \cdot 2$ \\
& 0.98 & $205 \cdot 5$ & $4 \cdot 2$ & $53 \cdot 3 \pm 1 \cdot 7^{*}$ \\
& 0.99 & 211 & $39 \cdot 6$ & $54 \cdot 0 \pm 2 \cdot 8$ \\
KG07(Hb) & 0.98 & 228 & $21 \cdot 6$ & $58 \cdot 9 \pm 2 \cdot 2$ \\
& 0.71 & 258 & $30 \cdot 8$ & $89 \cdot 8 \pm 2 \cdot 0$ \\
KG07(Bt) & 0.71 & 250 & 27.4 & $88 \cdot 4 \pm 2 \cdot 0$ \\
& $6 \cdot 2$ & 1305 & $4 \cdot 9$ & $53 \cdot 5 \pm 1 \cdot 2^{*}$ \\
\hline
\end{tabular}

*Analyzed at the Hiruzen Research Institute, Okayama University of Science, Okayama (Japan); others analyzed at the Teledyne Isotopes Co.

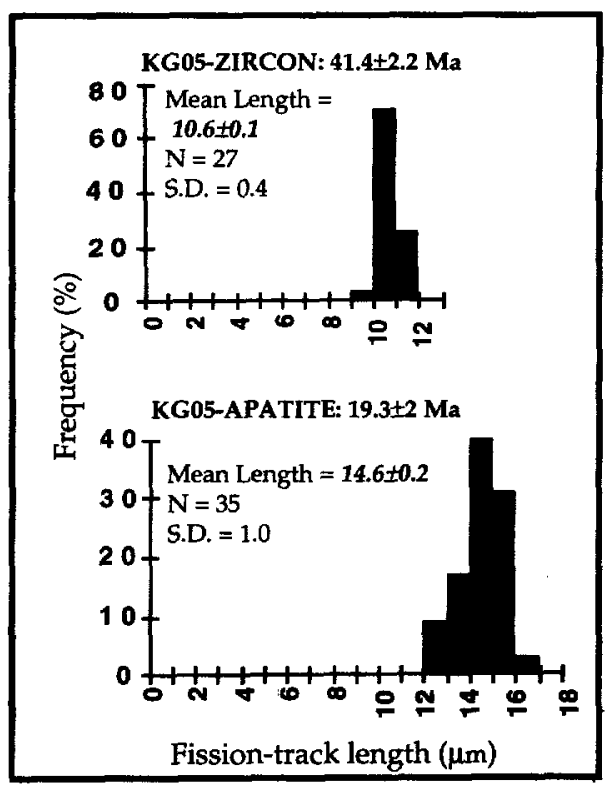

Figure 3. Fission track-length measurements of apatite and zircon for the sample KG05. $\mathrm{N}$ is the number of tracks and SD is the standard deviation of distribution.

and Choubey (1990), rendering our suggestion plausible. If this is true, then the Kirkichhu crush zone is a post-13 Ma event that took place under temperatures $\langle 100\rangle 60^{\circ} \mathrm{C}$ (corresponding to shallow crustal depths) that partially annealed apatite fission tracks in KG06. This is consistent with Sharma's observation that the north-south trending Kirkichhu crush zone (with $\sim 30 \mathrm{~m}$ thick mylonitisation) developed at brittle conditions (Sharma and Choubey 1990). Given this explanation, $\mathrm{KG} 06$ is excluded from the following discussion. 
Effective closure temperature of fission tracks in apatite has been determined to be $105 \pm 10^{\circ} \mathrm{C}$ for a cooling rate of $1-10^{\circ} \mathrm{C} / \mathrm{m}$.y. based on annealing experiments of fission tracks in apatite, comparison of apatite FT ages with other dating systems on the cooling history of a given pluton (i.e. thermochronologic systematics) and geological evidence from boreholes (Naeser 1976; Wagner et al 1977; Harrison and McDougall 1980 and references therein). The apatite ages obtained here indicate that rocks presently exposed in Kargil were experiencing temperatures of $\sim 100$ in the Early Miocene. This corresponds to depths of $3-4 \mathrm{~km}$ (now denuded), assuming an average geothermal gradient of $30^{\circ} \mathrm{C}$ for these continental rocks. There are several lines of evidence attributing this unroofing event to a major pulse of uplift that affected the Trans-Himalayan Batholith in the Early-Middle Miocene.

In recent years, it has been found out that Quxu pluton, which intruded at $42 \mathrm{Ma}$ (Scharer et al 1984b) as part of the Gandese Batholith in southern Tibet, rapidly uplifted and cooled at $18-21 \mathrm{Ma}$, evidenced by ${ }^{40} \mathrm{Ar} /{ }^{39} \mathrm{Ar}$ dating of biotite from rocks collected from a vertical profile $(3600-4600 \mathrm{~m}$ ) (Copeland et al 1987$)$, the ${ }^{40} \mathrm{Ar} /{ }^{39} \mathrm{Ar}$ age spectrum analysis of a single-grain K-feldspar sample (Richter et al 1991) and the FT analysis of apatite samples (Pan et al 1992). Our apatite FT ages are similar to the apatite ages of 19-25 Ma obtained by Pan et al (1992) for the Quxu pluton.

Track-length measurements on apatite from one sample (KG05; $19 \pm 2 \mathrm{Ma}$ ) yield a mean track-length of $14.6 \pm 0.2 \mu \mathrm{m}$ and a narrow range of length distribution (with standard deviation of $1 \mu \mathrm{m}$ ) (figure 3). This amount of track length for apatite is only slightly shorter than that of the Fish Canyon Tuff (an age standard in FT dating with an eruption age of $\sim 28 \mathrm{Ma}$ and track lengths of $\sim 15.3 \pm 0.3 \mu \mathrm{m}$ as reported by Gleadow et al 1986). It thus seems that the uplift of KG05 from complete annealing temperatures $\left(>120^{\circ} \mathrm{C}\right)$ to near surface temperatures has been very rapid.

Final testimony for the Early-Middle Miocene pulse of uplift and denudation in the Ladakh Range comes from the conglomerate beds of the same age occurring at the base of the Kargil (= Liyan) Formation, which occupies the upper parts of the Indus Molasse Group and is separated from the lower formations by a thrust (Mathur 1983).

Previous attempts to date apatite from the Kargil granitoids by the FT method were made by Lal and Nagpaul (1975), Sharma (1980) and Agarwal and Sharma (1986). Lal and Nagpaul (1975) reported apatite ages of $26 \pm 3,26 \pm 3,32 \pm 3,46 \pm 5$, and $46 \pm 4 \mathrm{Ma}$. Sharma (1980) determined a dozen apatite ages ranging from $16 \mathrm{Ma}$ through $22 \mathrm{Ma}$. Agarwal and Sharma (1986) reported apatite ages of $11 \pm 1,13 \pm 1$, $14 \pm 1,14 \pm 1$, and $16 \pm 1$ Ma. Compared to our new apatite FT apatite ages, those reported by Agarwal and Sharma (1986) are lower and those of Lal and Nagpaul (1975) are higher, but those determined by Sharma (1980) are comparable. We believe that this scattering of apatite ages from $\sim 12 \mathrm{Ma}$ (Agarwal and Sharma 1986) to $4.6 \mathrm{Ma}$ (Lal and Nagpaul 1975) does not carry any geological significance but is related to various qualities of experimental procedures; those employed by previous authors are now out-dated (Hurford 1990).

\subsection{Zircon fission-track ages}

Zircons from two samples (KG05 and KG07; figure 1d) were dated as $41 \cdot 4 \pm 2 \cdot 2 \mathrm{Ma}$ and $45.2 \pm 3.1 \mathrm{Ma}$, yielding a weighted mean age of $43 \pm 3.5 \mathrm{Ma}(2 \sigma)$. At present, FT closure temperature for zircon is not constrained experimentally; it is, however, 
estimated to be $225 \pm 25^{\circ} \mathrm{C}$ based on thermochronologic systematics (Zeitler 1985b; Hurford 1991 and references therein). The zircon ages from a quartz diorite (KG05) and a granodiorite ( $\mathrm{KG07)}$ indicates that these rocks now exposed have not been heated higher than $200-250^{\circ} \mathrm{C}$ during the past 40 million years. Previously, Agarwal and Sharma (1986) reported zircon FT ages of $52 \pm 3,61 \pm 5,62 \pm 4$, and $71 \pm 3 \mathrm{Ma}$, which seem to be higher than those obtained in this study, probably also due to different analytical procedures as explained above. Biotite separate from KG07 yields a $\mathrm{K}$-Ar age of $53.5 \pm 1 \cdot 2 \mathrm{Ma}$, corresponding to temperatures of $300 \pm 50^{\circ} \mathrm{C}$ (Wagner et al 1977; Harrison et al 1985).

Mean track length for the zircon sample KG05 was measured as $10.6 \pm 0.1 \mu \mathrm{m}$ with a standard deviation of $1 \mu \mathrm{m}$ (figure 3), which is only slightly shorter than the mean track length of the Fish Canyon Tuff zircon determined as $10.70 \pm 0.14 \mu \mathrm{m}$ with a standard deviation of $0.64 \mu \mathrm{m}$ (Tagami et al 1990). Such long track lengths in KG05 indicate rapid cooling of the rock during its uplift around $41 \mathrm{Ma}$.

It can be seen in figure 2 that zircon FT ages of $40-45 \mathrm{Ma}$ from the Kargil intrusives obtained in this study fall within the range of most biotite $\mathrm{K}-\mathrm{Ar}$ and $\mathrm{Rb}-\mathrm{Sr}$ ages (40-50 Ma), corresponding to closure temperatures of $250-350^{\circ} \mathrm{C}$ (Wagner et al 1977). These cooling ages from various parts of Ladakh, i.e. Kargil, Khaplu-Satpura, and Leh (figure $1 \mathrm{~b}$ ), probably record an Eocene pulse of tectonic uplift and ensuing erosion that affected the bulk of the Ladakh Batholith following the continental collision of India with the Ladakh arc at $\sim 55 \mathrm{Ma}$. Also note in figure 3 that KG05 shows a relatively rapid cooling between $55-41 \mathrm{Ma}$ (hornblende to zircon age). This uplift/erosion event is also inferred by the presence of Late Eocene-Early Oligocene conglomerates in Indus Molasse Group, which are rich in granitoid components (Frank et al 1977; Searle et al 1987).

Two $\mathrm{K}-\mathrm{Ar}$ ages on biotite separates from the Kargil granodiorite have been determined as $74.4 \pm 2.5 \mathrm{Ma}$ (Honegger et al 1982) and $71.6 \pm 2.1 \mathrm{Ma}$ (Frost et al 1984). These older ages show that some rocks had already cooled through $\sim 300^{\circ} \mathrm{C}$ following their formation in Upper Cretaceous.

From the cooling FT ages of zircon and apatite and their corresponding closure temperatures, it is possible to obtain average cooling rates. Dividing the cooling rate by a geothermal gradient (an average value of $30^{\circ} \mathrm{C} / \mathrm{km}$ assumed here), we can calculate unroofing (denudation rates (e.g. Wagner et al 1977) because cooling of rocks in orogenic belts occurs due to their uplift towards the surface. Figure 4 shows the timetemperature pathways of the samples $\mathrm{KG05}$ and $\mathrm{KG07}$ using their co-existing mineral dates. The rocks seem to have cooled at rates of $5-6^{\circ} \mathrm{C}$ and unroofed at a rate of $\sim 0.2 \mathrm{~mm} / \mathrm{yr}$ since Eocene. These are average rates over the time periods specified.

\subsection{Hornblende $\mathrm{K}$-Ar ages}

Hornblende $\mathrm{Ar}$ ages correspond to closure temperatures of $500-550^{\circ} \mathrm{C}$ (Harrison 1981). In this study we obtained three distinctly different $\mathrm{K}-\mathrm{Ar}$ ages on hornblende: $90 \pm 2 \mathrm{Ma}$ for $\mathrm{KG07}, 55 \pm 2 \mathrm{Ma}$ for $\mathrm{KG05}$, and $35 \pm 2 \mathrm{Ma}$ for $\mathrm{KG03}$ (figure 1c, d). These ages probably indicate the initial cooling stages of the rocks produced by three different plutonic activities in the Kargil area. This interpretation is explained below.

So far two zircon $\mathrm{U}-\mathrm{Pb}$ ages have been reported for two granodionites from Kargil: $103 \pm 3 \mathrm{Ma}$ (Honegger et al 1982) and $101 \pm 2 \mathrm{Ma}$ (Scharer et al 1984a). Several attempts (e.g. Honegger et al 1982; Klootwijik et al 1979, as well as author RBS) to 
determine a $\mathrm{Rb}-\mathrm{Sr}$ isochron for the $\mathrm{Kargil}$ intrusives have been unsuccessful due to insufficient spread in ${ }^{87} \mathrm{Rb} /{ }^{86} \mathrm{Sr}$ ratio and lack of homogenisation within the intrusive suite. The hornblende age of $90 \pm 2 \mathrm{Ma}$ obtained for the granodiorite sample (KG07) probably records the early-stage cooling of the 102-Ma Kargil granodiorite. A hornblende ${ }^{40} \mathrm{Ar} /{ }^{39} \mathrm{Ar}$ age of $82 \pm 6 \mathrm{Ma}$ was also reported from a syenite intruding the Dras Volcanics in south Kargil (Brookfield and Reynolds 1981). Frost et al (1984) have obtained two hornblende $\mathrm{K}-\mathrm{Ar}$ ages of $80.7 \pm 3.2 \mathrm{Ma}$ and $82.6 \pm 2.5 \mathrm{Ma}$ from the contact zone of the Kargil granitoids and Dras Volcanics. All these ages cluster at $\sim 85 \mathrm{Ma}$ corresponding to temperatures of $500-550^{\circ} \mathrm{C}$.

The 55-Ma hornblende age from the quartz diorite sample (KG05) is distinctly younger than that of KG07. Srimal (1986 and personal communication) has also determined similar hornblende ${ }^{40} \mathrm{Ar} /{ }^{39} \mathrm{Ar}$ ages $(\sim 50 \mathrm{Ma})$ from the Leh granites in eastern Ladakh, where the rocks have yielded a $\mathrm{Rb}-\mathrm{Sr}$ whole-rock isochron of $60 \pm 10$ (Honegger et al 1982) and a zircon U-Pb age of 60.7 $\pm 0.4 \mathrm{Ma}$ (Scharer et al 1984a). These hornblende ages seem to record the cooling through $500^{\circ} \mathrm{C}$ of the Ladakh granitoids intruded at $\sim 60 \mathrm{Ma}$. Although no such intrusive age has been reported from Kargil yet, further $\mathrm{U}-\mathrm{Pb}$ dating on zircon may reveal Palaeocene plutonic rocks in Kargil. KG05, which lies towards the core of the Ladakh batholith, possibly represents the Palaeocene plutonism in western Ladakh. It should also be noted that the hornblende age of KG05 (55 Ma) is similar to the biotite age of KG07 (54 Ma) possibly indicating relatively shallow-level intrusion of KG05. This has also been observed in the Leh area where granites yield close hornblende and biotite ages (Srimal 1986 and personal communication).

A hornblende $\mathrm{K}-\mathrm{Ar}$ age of $34.7 \pm 1.8 \mathrm{Ma}$ was determined for a diorite dyke in Kargil (sample $\mathrm{KG03}$ with a $\mathrm{SiO}_{2}$ content of 52.5 percent and ${ }^{87} \mathrm{Sr} /{ }^{86} \mathrm{Sr}$ ratio of $0.704452 \pm 0.000020$; geochemical data from plutonic and volcanic rocks of the Kargil area are to be published elsewhere). This age demonstrates the cooling of the diorite shortly after its intrusion in Late Eocene, perhaps marking the end phase of subduction-related I-type plutonism in Ladakh. Although the bulk of the Ladakh Batholith formed at $102-60 \mathrm{Ma}$ during the subduction-collision period, small plutonic masses and sheet injections continued rising even after the continental collision of India. This is geologically possible considering the time-lapse between the subduction of oceanic crust and the intrusion of calk-alkaline melts (Zhuo 1985). Late Eocene ages for granitoids have also been obtained from southern Tibet: A seven-point $\mathrm{Rb}-\mathrm{Sr}$ isochron of $38.8 \pm 1.3 \mathrm{Ma}$ in Kailash (Honegger et al 1982) and concordant $\mathrm{U}-\mathrm{Pb}$ ages of $41.5 \pm 0.5 \mathrm{Ma}$ from the Quxu pluton to the south of Lhasa (Scharer et al 1984b). Mention should also be made of a dacite dyke and a tonalite dyke in the Khaplu area yielding a biotite ${ }^{40} \mathrm{Ar} /{ }^{39} \mathrm{Ar}$ age of $42 \mathrm{Ma}$ (Brookfield and Reynolds 1981) and hornblende age of $39.7 \pm 0.2 \mathrm{Ma}$ (Reynolds et al 1983), respectively.

\subsection{Geodynamic implications of age data and scope for future work}

The genesis of the Ladakh granitoids, which are freshly exposed due to scarce soil and vegetation cover, has been an interesting subject of investigation for Himalayan geologists since 1860 s when F Stolickza surveyed Ladakh. To assess the present status of our geochronologic knowledge of the Ladakh Batholith, radiometric data reported in this paper as well as those determined by previous workers in the past three decades are synthesised in figure 2 . These geochronologic data in conjunction with 
geochemical data and geologic observations put significant constraints on the geodynamic evolution of the India-Asia collision in the Ladakh region. A plate-tectonic interpretation of the age data is presented below; and further necessary works are highlighted.

The 102-Ma intrusive phase in Kargil seems to be related to the Cretaceous islandarc type Dras volcanics as evidenced from both their formation ages and geochemical tendencies (Honegger et al 1982; Reuber et al 1989). This island-arc magmatism was different from the melts that generated the felsic calk-alkaline granites in Ladakh, such as those outcropping in Leh which intruded at $\sim 60 \mathrm{Ma}$ and show signatures of lower crustal contamination. Available isotopic data (Honegger et al 1982; Scharer et al 1984a) show that the Kargil granodiorites have $87 \mathrm{Sr} /{ }^{86} \mathrm{Sr}$ ratios of $<0.706$, while these values reach up to 0.710 for the Leh granites. Furthermore, Scharer et al (1984a) documented inherited radiogenic lead in zircons separated from the Shey granite near Leh. These chemical trends probably indicate the gradational input from the lower continental crust as we move from an island-arc environment in west Ladakh to an Andean-type margin in the east.

The fact that older magmatic ages are found for the Kargil granodiorite refutes the suggestion by Varadarajan et al (1980) that the Kargil granitic complex has formed by the remobilisation of the Ladakh granite, which is actually younger. We agree with Sharma and Choubey (1990) that the Kargil mafic intrusives represent the obducted base of the Dras island arc of Cretaceous age to the north of subducting Neo-Tethyan ocean floor.

It seems that the Ladakh block contains components of both an island arc (like Kohistan) and an Andean-type arc (like southern Tibet), the latter formed subsequently (Scharer et al 1984a; Raz and Honegger 1989). Whether the genesis of the Ladakh Batholith was restricted to the two major igneous phases of $102 \mathrm{Ma}$ and $60 \mathrm{Ma}$ or not is yet to be resolved definitely because the age data are too scanty to cover such a large plutonic complex. However, a Rb-Sr isochron of $73 \mathrm{Ma}$ (Scharer et al 1984a) from the Leh granite and a $\mathrm{Rb}-\mathrm{Sr}$ mica-whole rock isochron of $80 \mathrm{Ma}$ (Honegger et al 1982) from a Kargil granodiorite are limited evidence for multiple intrusive history. Additional zircon $\mathrm{U}-\mathrm{Pb}$ ages are needed to work out the complex magmatic history in Ladakh.

The hornblende ages of $80-90 \mathrm{Ma}$ probably record the cooling through $\sim 500^{\circ} \mathrm{C}$ of the 102-Ma Kargil granodiorite. It is interesting to note that this cooling event was coeval with an acceleration in the northward motion of the Indian plate shortly before $85 \mathrm{Ma}$ (Patriat et al 1982) and the subduction-related high pressure metamorphism of blueschists now preserved in the Indus Suture Zone (Honegger et al 1989). During this period, the Neo-Tethyan subduction slab seems to have dipped steeply as inferred from the tholeiitic composition of the Dras island arc at the base evolving to a shoshonitic composition at the top (Klootwijik et al 1979).

Following the closure of the Neo-Tethys ocean floor and the India-Asia continental collision at $55 \mathrm{Ma}$, a major pulse of uplift and erosion took place in Ladakh. This is evidenced from the mica cooling ages of $40-50 \mathrm{Ma}$ (figure 2) reported from various parts of Ladakh and zircon FT ages of $40-45 \mathrm{Ma}$ with track-length signatures of rapid cooling, as well as from the occurrence of granitoid influx to the Late Eocene-Early Oligocene sediments of the Indus Molasse Group. A R b-Sr biotite age of $39 \mathrm{Ma}$ (Desio and Zanettin 1970) from a granodiorite pebble in the Hemis Conglomerate (part of the Indus Molasse Group) (Frank et al 1977) supports the 
uplift/erosion scenario. The precise age of the Hemis Conglomerate is not known but has been estimated to be Late Eocene-Early Oligocene (40-30 Ma) (Thakur 1987; Garzanti and van Haver 1988 and references therein). Considering the closeness between the deposition (stratigraphic) age and the biotite cooling age of this granodiorite pebble, we infer that it probably took $<9$ million years for the granodiorite to have been uplifted from crustal depths of $\sim 10 \mathrm{~km}$ kilometres (corresponding to the geochronologic closure temperature of biotite) to the ground surface, and transported and deposited in the then Indus Basin lying to the south of the Ladakh Batholith. The coarse pebble size and petrographic composition of the Hemis Conglomerate testifies to this rapid uplift and erosion of the Ladakh Batholith in Late Eocene (Garzanti and van Haver 1988).

During Late Eocene, Ladakh experienced localised sheet injections of magma. We have already mentioned dykes dated as $35-40 \mathrm{Ma}$ in Ladakh. Many dykes have been mapped within the Ladakh Batholith (Raz and Honegger 1989; Rai 1983), and it is important to constrain the time of their emplacement because the dykes probably reflect a period of crustal tension in the region. The dykes vary in compositon, follow the joint patterns indicating that the host rocks were cooled, and most of them trend NNE-SSW (Rai 1983).

Here mention should also be made of pink porphyritic granites in eastern Ladakh (between Giak and Kiari, lying some 15 kilometres to the east of Hemiya). Trivedi et al (1982) reported a five-point $\mathrm{Rb}-\mathrm{Sr}$ isochron of $235 \pm 13 \mathrm{Ma}$ with an initial $\mathrm{Sr}$ ratio of $0.7081 \pm 0.0004$. This Permo-Triassic age stands odd among the radiometric data reported from the Ladakh Batholith, and reminds us of the pseudo-isochron of $264 \mathrm{Ma}$ for the Dras volcanics reported by Honegger et al (1982). Of the five points, the whole-rock isochron age of the Giak granite crucially depends upon one point (LKG0753) which shows a wide range in ${ }^{87} \mathrm{Rb} /{ }^{86} \mathrm{Sr}$ ratio (Trivedi et al 1982). Mineral (biotite-K feldspar-plagioclase) isochrons on two samples from the Giak granites, however, give ages of $30 \pm 1.5 \mathrm{Ma}$ and $29 \pm 1.5 \mathrm{Ma}$. Srimal (1986 and personal communication) has also determined a mineral (muscovite-biotite-K Feldspar) ${ }^{40} \mathrm{Ar} /{ }^{39} \mathrm{Ar}$ isochron of $27 \mathrm{Ma}$ for the Giak granite, which has intruded the Ladakh batholith. Sharma and Choubey (1983) have considered the Giak granite to be genetically unrelated to the Ladakh Batholith, and that it is a tectonic sliver of the Karakorum continental crust (the two-mica porphyritic granite of the Pangong Range) on the basis of its mineralogical composition and fault-bounded position. Ignoring the controversial $\mathbf{R b}-\mathrm{Sr}$ isochron of Permo-Triassic age until it is verified by additional measurements, we prefer to interpret the mineral isochrons of $\sim 30 \mathrm{Ma}$ as the formation age of the two-mica Giak granite in Ladakh. Similar acidic granitic sheets of 29-34 Ma have also been reported from the Kohistan block (Patterson and Windley 1985). It should be emphasized here that Late Eocene-Early Oligocene plutonism in Ladakh was very localised so that it did not reset the isotopic systems of hornblende and mica through the entire Ladakh Batholith.

From co-existing apatite and zircon ages in two samples, an average rate of $5-6^{\circ} \mathrm{C} / \mathrm{Ma}$ during the past 40 million years is calculated. Apatite FT ages of $20 \mathrm{Ma}$ in Kargil reveal an Early Miocene pulse of uplift and erosion, the sedimentary evidence of which is the Kargil Formation. Based on the ages and closure temperature of apatite $\left(\sim 100^{\circ} \mathrm{C}\right)$ it is estimated that $3000-4000 \mathrm{~m}$ of rocks have been denuded in Kargil during the past 20 million years. The Early Miocene uplift and denudation in the Ladakh Range may be related to a dramatic change in the geodynamic 


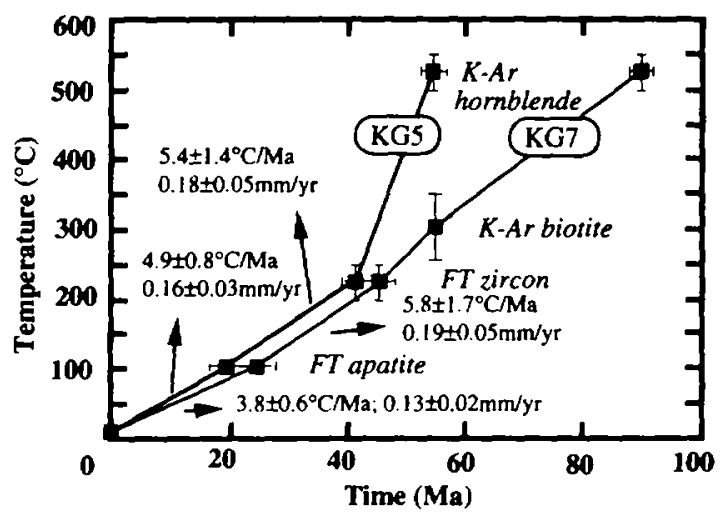

Figure 4. Cooling history of the samples KG05 (quartz diorite) and KG07 (granodiorite) from Kargil based on co-existing fission- track ages of apatite and zircon, and $\mathrm{K}$-Ar biotite and hornblende dates. Cooling and unroofing rates were calculated using the zircon-apatite-surface approach (Wagner et al 1977; Zeitler 1985a. Closure temperatures are described in the text. Surface temperature (present mean annual) was taken as $10 \pm 5^{\circ} \mathrm{C}$.

behaviour of the India-Asia collision from dominantly 'extrusion tectonics' of the Indo-China block along the Red River strike-slip fault and hence opening of the South China Sea during the Oligocene (Tapponnier et al 1986) to dominantly 'uplift/denudation tectonics' within the Himalayan zone during the Neogene after the cessation of the Indo-China block's extrusion. This interpretation has also been given to the Early Miocene uplift and erosion in southern Tibet (Copeland et al 1987).

Future fission-track geochronologic work in Ladakh, if concentrated on dating of samples from vertical profiles (river valleys to mountain peaks) and across major thrusts, will provide detailed information on the tectonic evolution of the Ladakh Range produced by the India-Asia collision.

\section{Acknowledgements}

RBS acknowledges a Monbushu scholarship provided by the Japanese Ministry of Education and Science which made it possible to undertake this study as part of his $\mathrm{PhD}$ thesis submitted to Kyoto University. AKJ, RM, and NL acknowledge financial help from the Department of Science and Technology (DST), New Delhi. We thank Professors V K Gaur, Edmund Stump, and two anonymous referees for their constructive comments on this paper, Neptune Srimal for personal communication, Sue Selkirk for her help with drafting of figure 1, and several residents of Kargil for their hospitality during our field work in 1987. Any error, however, is ours.

\section{References}

Agarwal S P and Sharma K K 1986 Thermal history of granitic rocks from Ladakh: a fission track dating technique; In: Nuclear Tracks: Applications to Earth Sciences, Space Physics and Nuclear Physics (ed) K K Sharma (Dehra Dun) pp. 1-18 
Brookfield M E and Reynolds P H 1981 Late Cretaceous emplacement of the Indus Suture Zone ophiolitic melanges and Eocene-Oligocene magmatic arc on the northern edge of the Indian plate; Earth Planet. Sci. Lett. 55 157-162

Copeland P, Harrison T M, Kidd W S F, Xu R and Yuguan Zh 1987 Rapid early Miocene acceleration of uplift in the Gandese Belt, Xizang (southern Tibet), and its bearing on accommodation mechanisms of the India-Asia collision; Earth Planet: Sci. Lett. 86 240-252

Desio A. Tongiorgi E and Ferrara G 1964 On the geological age of some granites of the Karakorum, Hindu Kush and Badakhshan (Central Asia); Proc. 22 Int. Geol. Cong. pp. 479-496

Desio A and Zanettin B 1970 Italian expedition to the Karakorum (K2) and Hindu Kush III, Geology and Petrology. 2 Geology of the Baltro Basin (Leiden: E J Brill) p. 296

Frank W, Gansser A and Trommsdroff V 1977 Geological observations in the Ladakh area (Himalayas): a preliminary report; Schweiz. Mineral. Petrogr. Mitt. 57 89-113

Frost D M, Sharma K K and Frost E G 1984 Mesozoic-Cenozoic magmatic evolution of the Indus Suture Zone, Ladakh: K-Ar age data; IASPEI Regional Assembly Hyderabad Abst. Vol. pp. 239-240

Galbraith G 1981 On statistical models of fission-track counts; Math. Geol. 13 485-488

Gansser A 1980 The significance of the Himalayan suture zone; Tectonophysics 62 37-52

Garzanti $E$ and van Haver T 1988 The Indus clastics: forearc basin sedimentation in the Ladakh Himalaya (India); Sediment. Geol. 59 237-249

Gleadow A J W, Duddy I, Green P F and Lovering J F 1986 Confined fission track lengths in apatite: a diagnostic tool for thermal history analysis; Contrib. Mineral. Petrol. 94 405-415

Green P F 1981 A new look at statistics in fission-track dating; Nucl. Tracks 5 77-86

Harrison T M 1981 Diffusion of ${ }^{\circ 0} \mathrm{Ar}$ in hornblende; Geochim. Cosmochim. Acta 44 1985-2003

Harrison T M and McDougall I 1980 Investigations of an intrusive contact, northwest Nelson, New Zealand, 1. Thermal, chronological and isotopic constrains; Geochim. Cosmochim. Acta 44 1985-2003

Harrison T M, Duncan I and McDougal! 11985 Diffusion of ${ }^{40} \mathrm{Ar}$ in biotite: temperature, pressure, and compositional effects; Geochim. Cosmochim. Acta 49 2461-2468

Honegger K, Dietrich V, Frank W, Gansser A, Thoni M and Trommsdroff V 1982 Magmatism and metamorphism in the Ladakh Himalayas (the Indus-Tsangpo Suture Zone); Earth Planet. Sci. Lett. 60 253-292

Honegger K, Le Fort P, Mascle G and Zimmermann J-L 1989 The blueschists along the Indus Suture Zone in Ladakh, NW Himalaya; J. Metamorphic Geol. 7 57-72

Hurford A J 1990 Standardization of fission-track dating calibration: recommendation by Fission Track Working Group of the IUGS Subcommission on Geochronology; Chem. Geol. (Isotope Geosci. Ser.) $80171-178$

Hurford A J 1991 Uplift and cooling pathways derived from fission track analysis and mica dating: a review; Geol. Rundsch. 80 349-368

Hurford $\mathrm{A} \mathrm{J}$ and Hammerschmidt $\mathrm{K} 1985{ }^{40} \mathrm{Ar} /{ }^{39} \mathrm{Ar}$ and $\mathrm{K} / \mathrm{Ar}$ dating of the Bishop and Fish Canyon Tuffs: calibration ages for fission-track dating standards; Chem. Geol. (Isotope Geosci.) 58 23-32

Klootwijik C 1984 A review of Indian Phanerozoic paleomagnetism: implications for the India-Asia collision; Tectonophysics $105331-352$

Klootwijik C, Shah S K, Sharma M L, Gergan J and Tirkey B 1979 The extent of greater India, II. Palaeomagnetic data from the Ladakh intrusives at Kargil, northwestern Himalayas; Earth Planet. Sci. Lett. 44 47-64

Lal N and Nagpaul K K 1975 Fission track geochronology of some Himalayan rocks; Himalayan Geol. 5 104-114

Mathur N S 1983 Age of the Kargil Formation, Ladakh Himalaya; In: Geology of Indus Suture Zone (eds) V C Thakur and K K Sharma (Dehra Dun: Wadia Institute of Himalayan Geology) 145-150

Naeser C W 1976 Fission-track dating; US Geol. Surv. Open File Report 76-190 1-65

Pan Y, Kidd W S F, Roden M K, Harrison T M and Copeland P 1992 Thermal and uplift history of the Gandese magmatic belt in Lhasa area, southern Tibet: evidence from apatite fission track analysis; 7th International Workshop on Fission-Track Thermochronology (Abst.) p. 85

Patriat $\mathrm{Ph}$ et al 1982 Les movements relatifs de I'Inde, de l'Afrique et de 'Eurasie; Bull. Soc. Geol. France 7 363-373

Patterson M G and Windley B F 1985 Rb-Sr dating of the Kohistan arc-batholith in the Trans-Himalaya of north Pakistan, and tectonic implications; Earth Planet. Sci. Lett. 74 45-57

Rai H 1983 The study of dyke swarms in the Kargil igneous complex Ladakh, Jammv and Kashmir, 
India; In: Stratigraphy and Structure of Kashmir and Ladakh Himalaya (ed) V J Gupta (Delhi: Hindustan Publishing Corporation) pp. 263-275

Rai H and Pande I C 1978 Geology of the Kargil igneous complex, Ladakh, Jammu and Kashmir, India; Recent Res. Geol. 5 219-228

Raz U and Honegger K 1989 Magmatic and tectonic evolution of the Ladakh block from field studies; Tectonophysics 61 107-118

Reuber I, Montigny R, Thuizat R and Heitz A $1989 \mathrm{~K}-\mathrm{Ar}$ ages of ophiolites and arc volcanics of the Indus suture zone: clues on the early evolution of the Neo-Tethys; Eclog. Geol. Helv. 82 699-715

Reynolds PH, Brookfield M E and McNutt R H 1983 The age and nature of Mesozoic-Tertiary magmatism across the Indus Suture Zone in Kashmir and Ladakh (N. W. India and Pakistan); Geol. Rundsch. 72 981-1004

Richter F M, Lovera O M, Harrison T $M$ and Copeland P 1991 Tibetan tectonics from ${ }^{40} \mathrm{Ar} /{ }^{39} \mathrm{Ar}$ analysis of a single K-feldspar sample; Earth Planet. Sci. Lett. 105 266-278

Saxena $M$ N and Miller $I$ A 1972 Metamorphism, magmatism and orogeny in the light of radiometric dates in northwestern Himalaya: Bull. Indian Geol. Assoc. 5 63-69

Scharer U. Hamet $J$ and Allegre C J 1984a The Trans-Himalayan (Gandese) plutonism in the Ladakh region: U-Pb and Rb-Sr study; Earth Planet. Sci. Lett. 67 327-339

Scharer U, Xu R H, Allegre C J 1984b U-Pb geochronology of the Gandese (Transhimalayan) plutonism in the Lhasa-Xigase region, Tibet; Earth Planet. Sci. Lett. 69 311--320

Searle M P et al 1987 The closing of Tethys and the tectonics of the Himalaya; Geol. Soc. Am. Bull. 98 678-701

Sharma K K and Choubey V M 1983 Petrology, geochemistry and geochronology of the southern margin of the Ladakh Batholith between Upshi and Chumathang; In: Geology of Indus Suture Zone (eds) V C Thakur and K K Sharma (Dehra Dun: Wadia Institute of Himalayan Geology) pp. 41-60

Sharma K K and Choubey V M 1990 Kargil igneous complex: an obducted base of Dras island arc; In: Geology and Geodynamic Evolution of the Himalayan Collision Zone (Physics and Chemistry of the Earth) (ed) K K Sharma 17 155-171

Sharma O P 1980 Solid State Nuclear Track Detectors: Annealing Studies and Geophysical Applications; Ph.D thesis. Kurukshetra University (India)

Srimal N 1986 Geology and oxygen, strontium and ${ }^{10} \mathrm{Ar} /{ }^{39} \mathrm{Ar}$ isotopic study of India-Asia collision zone in the Ladakh and Karakoram, NW India; Ph.D thesis, University of Rochester (USA)

Steiger R H and Jager E 1977 Subcommission on geochronology: convention on the use of decay constants in geo- and cosmochronology; Earth Planet. Sci. Lett. 36 359-362

Tagami T, Ito $\mathrm{H}$ and Nishimura S 1990 Thermal annealing characteristics of spontaneous fission tracks in zircon; Chem. Geol. (Isotope Geosci.) 80 159-169

Tagami T, Lal N, Sorkhabi R B, lto $H$ and Nishimura S 1988 Fission track dating using external detector method: a laboratory procedure; Mem. Fac. Sci., Kyoto Univ., Geol. and Mineral. Ser. 53 1-30

Tapponnier P, Pelzer P and Armijo R 1986 On the mechanics of the collision between India and Asia; In: Collision Tectonics (eds) M P Coward and A C. Ries (Geol. Soc. Sepc.. Publ. London 19) pp. 115-157

Thakur V C 1987 Plate tectonic interpretation of the western Himalaya; Tectonophysics 134 91-102

Treloar P J et al $1989 \mathrm{~K}-\mathrm{Ar}$ and Ar-Ar geochronology of the Himalayan collision in NW Pakistan: constrains on the timing of suturing, deformation, metamorphism, and uplift; Tectonics 8 818-909

Trivedi J R, Gopalan K, Sharma K K, Gupta K R and Choubey V M 1982 Rb-Sr age of Giak granite, Ladakh Batholith, northwest Himalaya; Proc. Indian Acad. Sci. (Earth Planet. Sci.) 91 65-73

Varadarajan S, Uppal U S and Vashist N 1980 Petrography and geochemistry of Kargil granitic complex, Ladakh region, NW Himalaya; Proc. 3rd Indian Geol. Cong. (Poona) 461-473

Wagner G A, Reimer G M and Jager E 1977 Cooling ages derived by apatite fission track, mica Rb-Sr and K-Ar dating: the uplift and cooling history of the Central Alps; Mem. Inst. Geol. Mineral. Univ. Padova 30 1-27

Zeitler P K 1985a Cooling history of the NW Himalaya, Pakistan; Tectonics 4 127-151

Zeitler P K $1985 \mathrm{~b}$ Closure-temperature implications of concordant ${ }^{40} \mathrm{Ar} /{ }^{39} \mathrm{Ar}$ potassium feldspar and zircon fission-track ages from high-grade terrains; Nuclear Tracks (Abst.) 10 441-442

Zhuo $\mathrm{J} 1985$ The timing of calk-alkaline magmatism in parts of the Alpine-Himalayan collision zone and its relevance to the interpretation of Caledonian magmatism; J. Geol. Soc. London 142 309-317 